\title{
TRENDS IN PRODUCTION AND PROCESSING OF MEAT IN THE REPUBLIC OF SRPSKA
}

\author{
Aleksandar OSTOJIĆ, Ph.D., associate professor in marketing and management \\ in agriculture \\ Faculty of Agriculture, \\ University Banja Luka, \\ Address: $\quad$ Bulevar vojvode Petra Bojovica 1A,78000, Bosnia and Herzegovina, \\ Phone: $\quad+38751330926,+38751312580$ \\ Email: $\quad$ aleksandar.ostojic@agrofabl.org
}

Ljiljana DRINIC, Ph.D., associate professor in rural entrepreneurship

Faculty of Agriculture,

University Banja Luka,

Address: Bulevar vojvode Petra Bojovica 1A,78000, Bosnia and Herzegovina,

Phone: $\quad+38751330926,+38751312580$

Email: $\quad$ ljiljana.drinic@agrofabl.org

Nebojša NOVKOVIĆ, Ph.D., professor in management and organisation in agriculture, Faculty of Agriculture

University Novi Sad,

Address: $\quad 21000$, Srbia,

Phone: +381-21-4853-399

Fax: $\quad+381-21-6350-822$

Email: $\quad$ nesann@ polj.uns.ac.rs

Gordana ROKVIC, M.Sc., assistant in rural development

Faculty of Agriculture,

University Banja Luka,

Address: Bulevar vojvode Petra Bojovica 1A, 78000 , Bosnia and Herzegovina,

Phone: $\quad+38751330928,+38751312580$

Email: $\quad$ gordana.rokvic@agrofabl.org 


\title{
TRENDS IN PRODUCTION AND PROCESSING OF MEAT IN THE REPUBLIC OF SRPSKA
}

\author{
Key words: \\ Livestock production, production and processing of meat, trends, Republika Srpska
}

\begin{abstract}
:
In the Republic of Srpska (Entity of Bosnia and Herzegovina), livestock, especially cattle and sheep, have a long tradition. The potential for the development of animal husbandry is a major, taking into account the available land capacity. On the other hand, consumption of proteins of animal origin grows proportionally with the increase in living standards. EU countries are also moving away from the strategy of further intensification of production of animal products because it would have meant even greater pressure on land resources, biodiversity, and quality and safety of products, and this is not what European producers now want. This situation creates room for producers from RS to create supply for the European market. The aim of this paper is to demonstrate the capabilities and trends in meat production in the Republic of Srpska, and the willingness of this part of the RS economy to compete in the European market. The authors used the method of comparative analysis to observe the livestock and meat production in the RS in the period 2005-2011.
\end{abstract}

\section{Кључне речи:}

сточне производње, производња и прерада меса, трендови, Република Српска

\section{Сажетак:}

Трендови у производња и преради меса у Републици Српској У Републици Српској (Ентитет Босне и Херцеговине), сточарство, а нарочито узгој говеда и оваца, имају дугу традицију. Потенцијал за развој сточарства је велик, узимајући у обзир расположиве капацитете земљишта. С друге стране, потрошња протеина животињског порекла расте пропорционално са повећањем животног стандарда. Земље ЕУ не могу да задовоље потребе протеина животињског порекла из сопствених извора. Земље ЕУ се такође удаљавају од стратегије даљег интензивирања производње анималних производа, јер би то значило још већи притисак на одрживо кориштење земљишних ресурса, биодиверзитет и квалитет и безбедност производа, а то није оно што европски произвођачи сада желе. Ова ситуација ствара простор за произвођаче из РС да створе залихе за европско тржиште. Циљ овог рада је да покаже могућности и трендове у производњи меса у Републици Српској, као и спремност овог дела привреде РС да се такмиче на европском тржишту.

Аутори су користили метод упоредне анализе за посматрање обима сточарске производње и производње меса у РС у периоду 2005-2011.

\section{INTRODUCTION}

In the RS there are climatic, geographic, and socio-economic conditions for the development of agriculture, especially livestock. The rapid development of the organized commercial agriculture is disturbed by small and fragmented land (small plots of land), technical knowledge of producers (modern methods and the latest developments in agriculture), availability of raw materials (seeds, breeding materials, plant protection, fertilizer) as well as lack of funds and reducing the purchasing power of most of the population. On the other hand, consumption of proteins of animal origin grows 
proportionally with the increase in living standards. Thus, the consumption of these types of proteins in the EU is twice the world average and the trend is increasing because of growth in living standards, due to EU enlargement and increase of population. EU countries cannot meet the needs of the proteins of animal origin from its own resources. EU countries are also moving away from the strategy of further intensification of production of animal products because it would have meant even greater pressure on land resources, biodiversity, and quality and safety of products, and this is not what European producers now want (European Commission, 2010). This situation creates room for producers from RS to create supply for the European market. The aim of this paper is to demonstrate the capabilities and trends in meat production in the Republic of Srpska, and the willingness of this part of the RS economy to compete in the European market.

\section{OBJECTIVES AND METHODS}

The authors used the method of comparative analysis to observe the livestock and meat production in the RS in the period 2005-2011. The analyzes investigates the trends in the growth of livestock number, as well as the quantity of meat produced, calculated on the basis of the base index, with 2005 as base year. The data sources used were official publications of the Institute of Statistics.

The level of the trade balance has been analyzed trough the value of foreign trade, imports and exports for the period 2005-2009, for which period data were available. The data are taken from official publications of the Foreign Trade Chamber of $\mathrm{BiH}$ and relate to $\mathrm{BiH}$ as a country, given that the foreign trade exchange is in the jurisdiction of the state rather than entity in Bosnia.

\section{RESULTS AND DISCUSSION}

\section{The situation of livestock production in the $\mathrm{RS}$}

The available arable land is very important for the development of agricultural production, notably livestock production. There is available, in average, around 988.000 ha in the Republic of Srpska (Fig. 1.).

Fig. 1 Structure in RS for 2009.

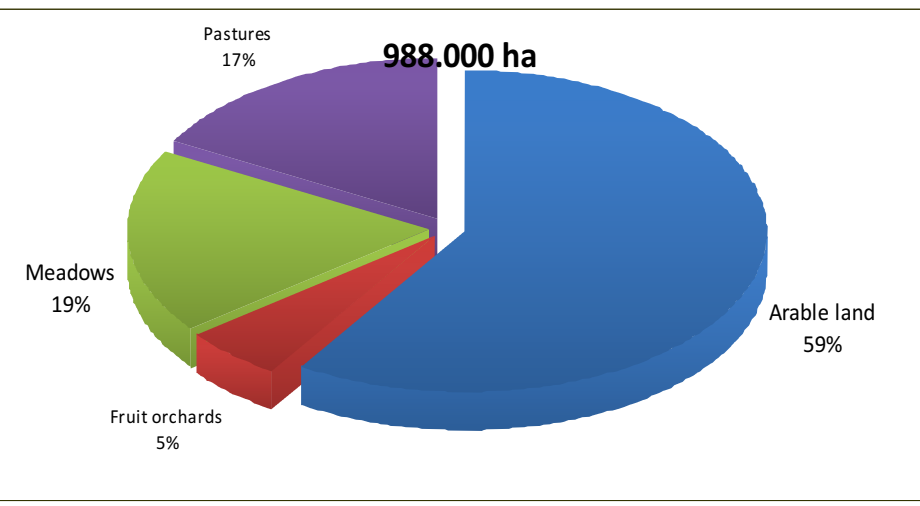

of sown area 
Source: Statistical Annual Bulletin ISSN 2232-7312, Banja Luka, December, 2010. p.149

- At 70-80 000 ha - forage crops are cultivated annually,

- On average 147000 hectares annually produces about 550000 tons of maize,

- At average of 3.5 thousand ha - about 6.5 thousand tons of soybeans are produced annually,

- The area of sown arable land (in 2009 - $368000 \mathrm{ha}$ ), about $1 / 2$ is in use for production of production of fodder.

In the RS agriculture, livestock production has great economic importance. Status and development of livestock production is the most reliable indicator of the development of agrarian sector of any country, including the RS. The significance of the development of livestock production is reflected in the fact that the ruminants exploit surface under natural grasslands (meadows and pastures), which in the structure of agricultural land covers about $36 \%$. Figure 2 shows the level of livestock production in the Republic of Srpska for the period 2005-2011 analyzed for cattle, sheep, pigs and poultry.

Fig. 2 The livestock production in the RS, number of heads per year for the period 20052011

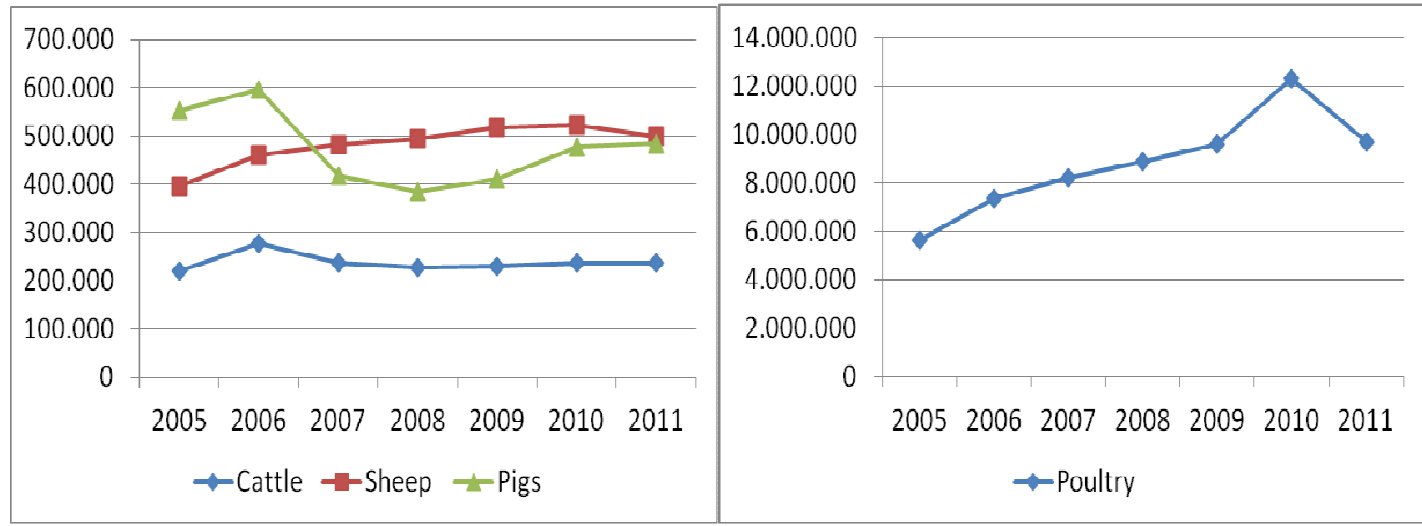

Source: Statistical Annual Bulletin ISSN 2232-7312, Banja Luka, December, 2010. p.162 
In terms of number of the individual types of livestock it can be seen that the number of poultry and sheep in the seven-year period had an increasing trend, while in cattle and pigs, although the first year, recorded an increase, the number of cattle in the last years has declined. According to the indices of production for the base year 2005, we can conclude that all species of livestock other than pigs had a positive index value. The average growth in cattle production compared to 2005 was $8.89 \%$ per year, with highest values in 2006 and the lowest in 2008. Production of sheep had an average increase of $25.29 \%$ per year, with highest values in 2010, and lowest in 2006. Production of pigs has not reached the level of production in 2005 and the average index compared to this year was only $83.17 \%$. The lowest index was recorded in 2008 when total production fell to $69.37 \%$ of production in 2005. Poultry production has, as stated above, the highest growth with an average annual rate of $66.14 \%$. The greatest value of poultry production has being reached in 2010 with over $200 \%$ growth index compared to 2005, but in 2011 this index has declined by $30 \%$ (Figure 3.)

Fig. 3 The indexes of the RS livestock production (2005-2011)

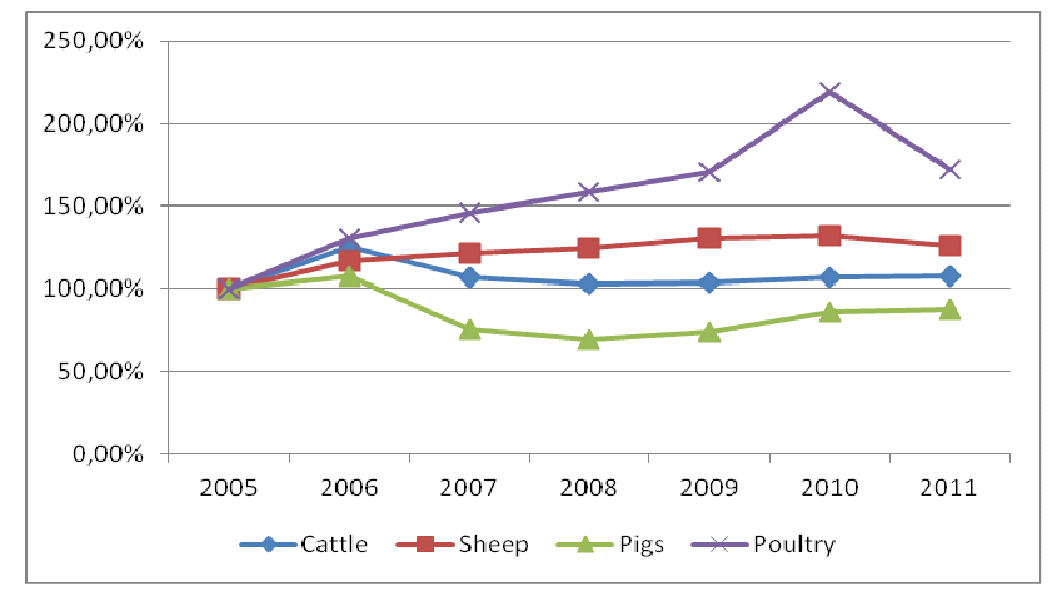

Source: Own calculation

Analysis of meat production showed somewhat different trends of total production and growth indices during the analyzed period. Cattle as one of the most important branches of livestock production in the RS are very widespread and are present in most farms. During the monitoring period, the average production of beef was 5.852,46 tons. However, production indices show negative growth and that the level of production throughout the analyzed period fall below the level of production in 2005 and fluctuated around an average of $79.10 \%$. The largest decline in beef production was in 2007 , when we saw the fall in 
livestock production in the RS. This leads to the conclusion that the production of beef is directly dependent on the production of livestock or the number of beef in RS.

Pig production, in addition to cattle breeding and poultry production, is a very important branch of animal production. According to statistics, the total production of (pork) meat for the monitoring period ranged, on average, around 6.028.73 tons. For the monitoring period, on average, pork production per capita was about $3 \mathrm{~kg}$, which is very low production, especially if you consider the possibilities of this production in RS. Pork production indices show an extremely high value of the average growth of $54.67 \%$ per annum, as compared with negative growth in the number of pigs. This is evidence of increased imports of pigs in the RS and the loss of local ties inoculants production and processing in the pig production.

Sheep production in the RS is most prevalent in the hilly mountainous areas, which are rich in large parts of the natural pastures. The RS is characterised mainly with the extensive production of sheep, with a mixed production of meat, milk and wool. Production of sheep meat is modest compared to other meat types. Average annual quantity is around 170 tons. But we have to take into account that, traditionally, sheep meet is marketed trough direct sales which is not recorded by statistical office. Index of sheep meat production averaged 25.29\% annually compared to 2005 and had a steady growth since 2006 (Figure 4.).

Fig. 4 The volume and index of meat production in RS, number of heads and tones of meat, (2005-2011)

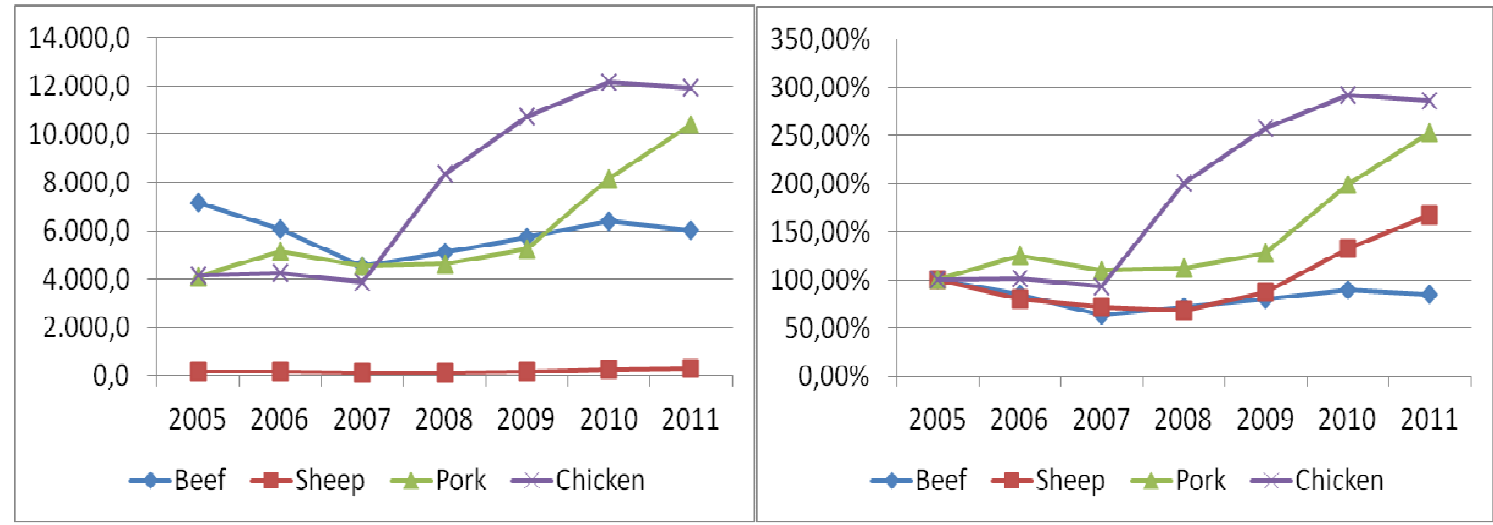

Source: Statistical Annual Bulletin ISSN 2232-7312, Banja Luka, and own calculation

Processed meat, especially dry and smoked meat, is a tradition in the RS, which lasts for centuries. What started as just one of many activities that are performed in a household, and then turned into a cottage industry, today represents a significant portion of the food sector. RS with its own present production is unable to close the balance of meat and therefore larger quantities of meat are imported, especially for processing. Those are primarily economic reasons, i.e. the global market offers a large quantity of frozen meat, much 
cheaper than domestic production, but poor quality. Low prices of imported meat have disincentive effect on domestic production of meat (Mirjanić et al., 2010, 2011).

During the monitoring period in the RS, the amount of purchased livestock for slaughter has increased, and increase in the total quantity of meat originating from local slaughterhouses, especially in poultry (Figure 5).

Fig. 5 The amount of meat and meat products in the period 2006-2009

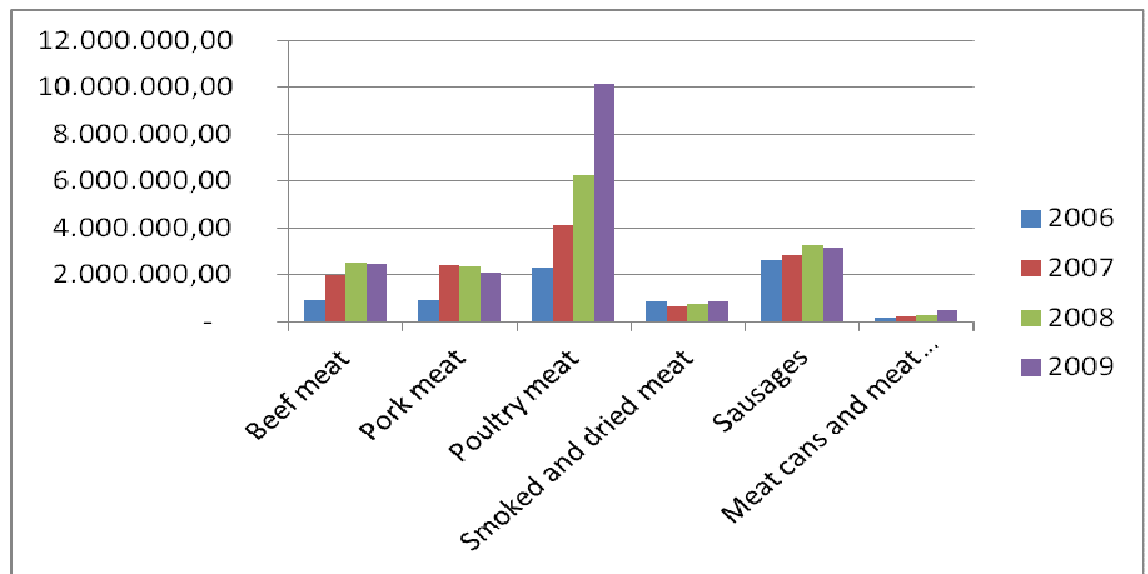

Source: Statistical Annual Bulletin ISSN 2232-7312, Banja Luka, December, 2010.god. Industrija, p.191

According to the relevant ministry ${ }^{3}$ in 2008 , RS processed 2.506 tons of beef, 2.329 tons of pork and 6.616 tons of chicken meat. In the processing of beef and chicken meat a significant increase was noted, while in the production of pork, slight decrease was noted in comparison with the previous year. With respect to meat processing, production of sausages and canned products increased. According to the same source, the capacity of meat processing industry in the RS use only $20-25 \%$ capacity, which indicates their low level of usage. In addition, many do not meet the required standards, which is one of the reasons for their poor competitiveness in international markets.

According to MoA total number of processing capacities is 262, of which only 35 industrial buildings and $226 \mathrm{craft}$, out of 35 industrial facilities, 12 are into bankruptcy or ceased operations.

\section{Foreign trade}

Foreign trade of agricultural products and foodstuffs of $\mathrm{BiH}$, and RS within, showed chronic deficits (Figure 6).

\footnotetext{
${ }^{3}$ Information on status and conditions in food industry in RS in 2008. MAFWM RS, 2009, p.5.
} 
Fig. 6 Balance of exports and imports of meat and meat products on the $\mathrm{BiH}$ level

Source: Own calculation

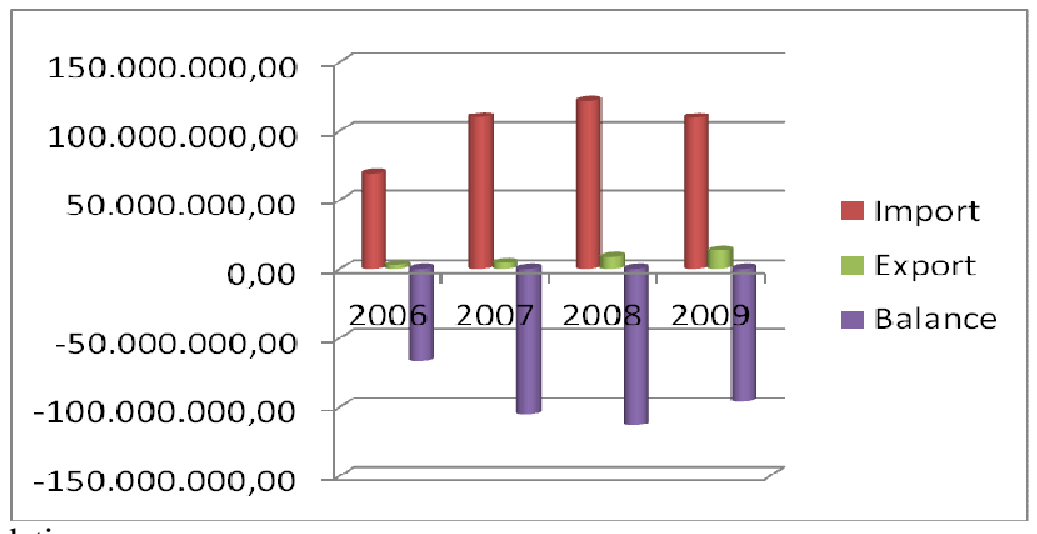

The opportunities of placement of meat in foreign markets are evident, but this placement is limited to a certain number of countries. In most cases, the exports of meat are due to incompatibility of veterinary-sanitary regulations with regulations in the environment. In addition, there is insufficient motivation of primary production to enter into commercial production.

Then, failure of basic safety standards, improper organization of purchasing, quality inconsistency, lack of knowledge of foreign markets, are just some of the reasons why the potential for exports, which exists in this sector, is not used.

Table 1 Bosnia and Herzegovina and the EU trade of agricultural products

\begin{tabular}{|c|c|c|c|c|c|c|c|}
\hline $\begin{array}{c}\text { EU } \\
\text { import } \\
\text { from BiH } \\
\text { (in mil. €) }\end{array}$ & 2008 & 2009 & 2010 & $\begin{array}{c}\text { EU export } \\
\text { to } \mathrm{BiH} \text { (in } \\
\text { mil. } € \text { ) }\end{array}$ & 2008 & 2009 & 2010 \\
\hline Sugar & 7,5 & 6,5 & 7,0 & Cereals & 79,2 & 28,4 & 39,5 \\
\hline Fruits & 6,2 & 7,1 & 10,6 & $\begin{array}{l}\text { Dairy } \\
\text { products, } \\
\text { eggs, } \\
\text { honey }\end{array}$ & 27,9 & 26,2 & 36,6 \\
\hline Vegetable & 3,6 & 5,4 & 8,9 & Sugar & 8,9 & 8,5 & 8,2 \\
\hline $\begin{array}{l}\text { Leather } \\
\text { and fur }\end{array}$ & 26,8 & 16,6 & 36,3 & $\begin{array}{l}\text { Meat and } \\
\text { meat } \\
\text { products }\end{array}$ & 20,1 & 24,8 & 29,5 \\
\hline Oils & 5,5 & 10,4 & 10,8 & Oils & 18,6 & 23,5 & 21,6 \\
\hline
\end{tabular}

Source: Statistical Annual Bulletin ISSN 2232-7312, Banja Luka, December, 2010.god

Based on the above review (Table 1) it is clear that $\mathrm{BiH}$ and the $\mathrm{RS}$ do not use the comparative advantages in the production of meat, but on the contrary, they appear as a net importer of meat from the European Union. 


\section{The market chain in meat production and processing}

The market chain in meat production is largely unorganized and short, because a large part of production ends within the household or in local markets (official and unofficial). One part of the production, however, is collected/purchased through the slaughterhouses, directly or through intermediaries, making it possible to extend the chain of production thus generating additional value of the product. Small amounts of meat products are exported to neighbouring countries (Albania, Serbia, Croatia), Figure 7.

Fig. 7 The value and the ratio of imports and exports of meat products in $\mathrm{BiH}$ with neighbouring countries and EU, 2010
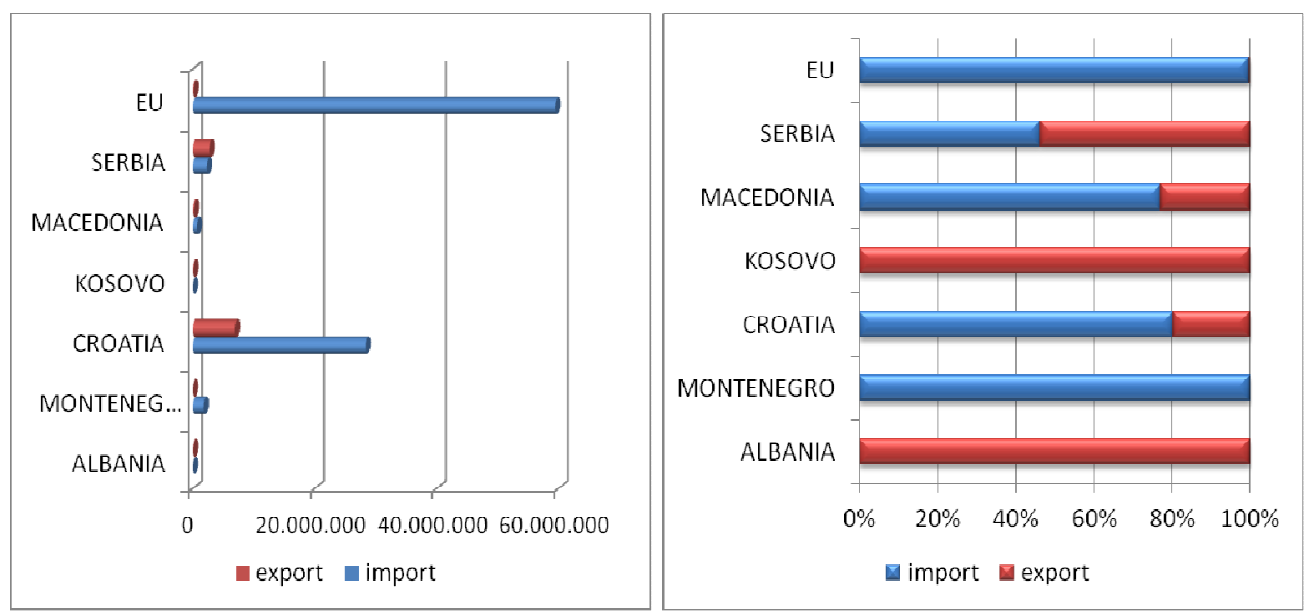

One of the main reasons for short market chain is that a significant portion of production is in the hands of small producers, mainly with extensive production. The largest portion of meat is produced by family farms that are commodity producers with ten bullocks, a hundred pigs and sheep and in recent years, there is a tendency to increase Poultry production with 10000 chickens for fattening. There are also organized producers (relatively large producers for the conditions of production in the RS) who fatten cows on their own farms or in the organized fattening on member farms. This situation indicates that production can be distinguished in three groups of producers of meat, that are determined by different production and sales market chains, ${ }^{4}$ Table 2.

\footnotetext{
${ }^{4}$ National Program of rural development of Serbia 2011-2013, Belgrade, 2011.
} 
Table 2 Market chains in the production of processed meat in RS

\begin{tabular}{|c|c|c|}
\hline Small producers & Commercial producers & Relatively large producers \\
\hline 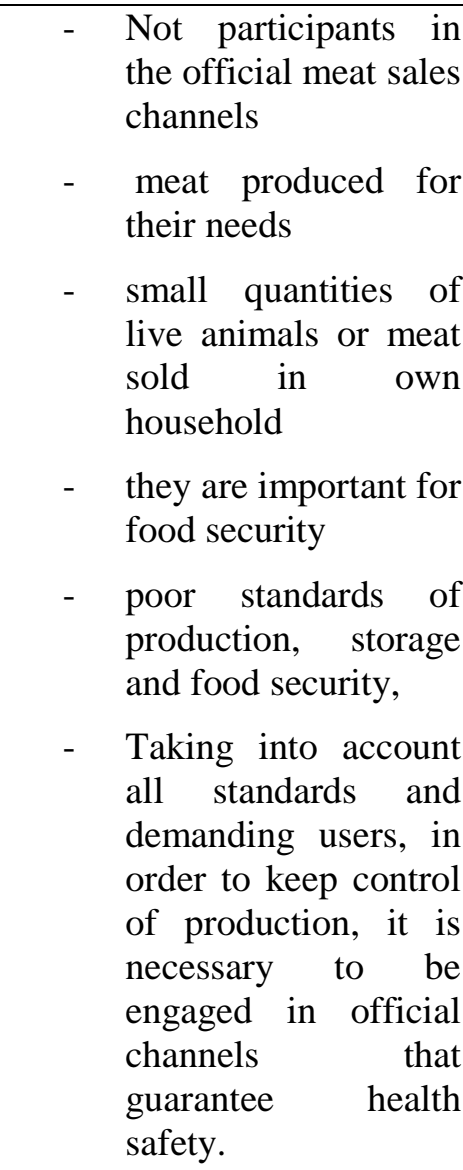 & 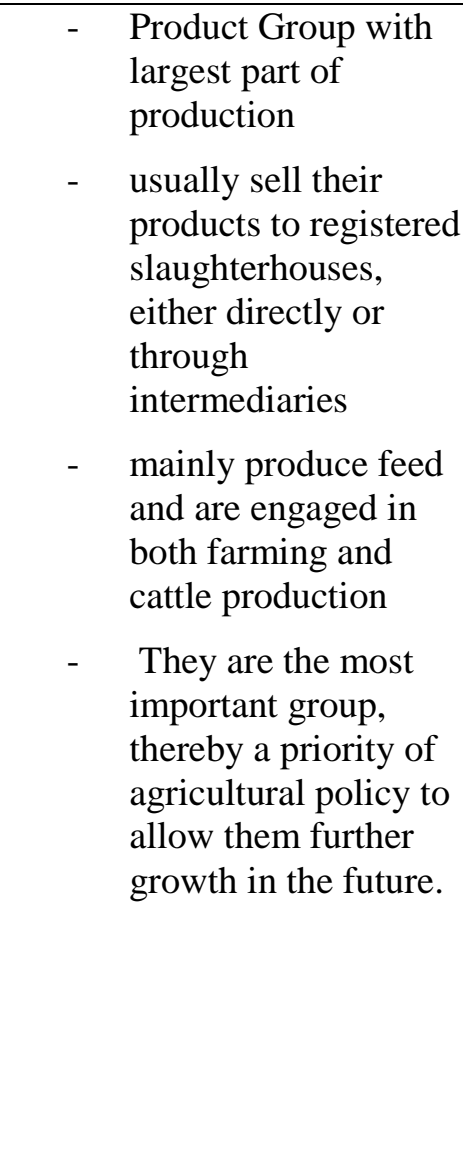 & $\begin{array}{l}\text { Companies engaged } \\
\text { in the production of } \\
\text { animal feed, } \\
\text { processing or selling } \\
\text { of meat trying to } \\
\text { establish a vertical } \\
\text { connection, which } \\
\text { would reduce the } \\
\text { market or price } \\
\text { fluctuations that are } \\
\text { characteristic for } \\
\text { meat production } \\
\text { In addition to them, } \\
\text { there are companies } \\
\text { that saw their } \\
\text { opportunity for profit } \\
\text { in meat producing } \\
\text { and through the } \\
\text { privatization process } \\
\text { came to productive } \\
\text { resources }\end{array}$ \\
\hline
\end{tabular}

Medium-sized producers are most important from the perspective of agricultural policy, because the biggest production is done by them in all areas of meat (beef, pork, lamb and poultry).

\section{Reform of the CAP as a chance for producers of meat in RS}

Livestock sector of the EU had a steady growth in recent decades. The old EU12 Member States had the strongest growth in the period 1961-1985, when milk production increased by $70 \%$, pigs by $120 \%$ and poultry by $300 \%$. Production of beef and milk stagnated after 1985, mainly as a result of changes in the CAP. Production of pig and poultry continued to grow by around $4 \%$ per annum. Today the EU is a net importer of beef and mutton, and a net exporter of pork and dairy products.

Livestock production in the EU is heavily influenced by the Common Agricultural Policy - CAP. Although the CAP in the last few decades has experienced significant reforms and further characterized by direct subsidies and export taxes that exist for most livestock 
products. Long-time negotiations within the World Trade Organization - WTO on the reduction of export subsidies for EU products can cause a rise in prices of livestock products from the EU, taking into account production costs suffered by EU producers. Therefore, the sharp sanitary regulations that the EU imposes on imported products of animal origin, are the how the EU protects the domestic market.

Apart from market measures next important factor that can affect change CAP in terms of support for livestock production is the impact of this kind of production on the environment and ecological factors. Feed production requires large amounts of land, water and other inputs, and produces large amounts of nitrogen and leads to the greenhouse effect. Livestock production accounts for about $10 \%$ of total greenhouse gas emissions at the EU level. About $75 \%$ protein livestock feed needed in the EU production are covered from imports, mainly soybeans from countries of South America, allowing the EU to indirectly affect the environmental factors of production outside its territory.

Directly related to livestock production were also questions about the conditions of keeping animals and animal health care. The last 10-15 years the EU market was disturbed by the great crises ranging from mad cow disease and foot-and-mouth disease, bird flu, swine fever, etc.

All these factors influence the policy to support livestock production from the EU budget, and on the other side on the preferences of EU consumers. No EU tax payers want to set aside money for the production of products of suspicious quality, which is, in addition, disrupt the balance of the environment, neither the EU consumers want to consume such products. Awareness of EU consumers therefore moves in the direction of consuming products that are produced in an environmentally healthy area, which meet their quality and hygiene standards (The European Union, PBL Netherlands Environmental Assessment Agency, 2011).

\section{CONCLUSION}

In the Republic of Srpska a relatively small amount of meat is produced, with respect to the available natural resources. Therefore, this is a limiting factor in supply in the domestic and foreign markets. On the other hand, coming closer to the EU market and the characteristics of demand in this market provide an opportunity for domestic producers to increase production for export. Therefore, there is a need to increase livestock production through: 
- better organization of fattening cattle in terms of compliance capacity of primary and secondary production, and development of strategic orientation in the production and processing of meat, in this sense to harmonize the institutional, political and economic support systems prevailing in the country with the strategic orientation of sectoral policies;

- improving the quality of production especially in terms of ensuring continuity and quality level, in this sense, the introduction of quality grades of carcasses at slaughter, especially in pigs, go to the system of buying meat per unit and not kilo, hence producers would be stimulated and rewarded for better quality meat in its production;

- improve the situation in the meat production and processing by economic measures, which occurs as a necessary precondition for export, but also use preaccession funds, including making available soft lending to investment in livestock production, and systematic support measures that would be compatible with economic and organizational rules in livestock;

- encourage efficient forms of cooperation between producers, feed industry for poultry and processing industries and in that sense, support the establishment of agricultural chambers, which would bring together representatives of all sectors in the chain and allow the establishment of rules and agreements in the field of production and market agricultural products;

- Establishing laboratories for testing the quality of meat, and accrediting them, in order to adequately monitor the quality and provide support of local institutions to the export of products of animal origin

- an increase of work on prevention and combating of infectious diseases in order for $\mathrm{BiH}$ to obtain a license for the export of products of animal origin;

Taking into account the resources available and the needs of European consumers for high quality protein of animal origin, one of the strategic orientations of Srpska in the period before accessing the European Union could be the production of animal products, i.e. primarily meat for the European market.

\section{Summary}

One of the strategic objectives of economic policy of each country is to improve food production, in order to attain the higher level of self-sufficiency in food needs. On this basis, it follows that meat production is a very important resource for food production, so that production is given adequate attention both legal and institutional. In the Republic of Srpska (Entity of Bosnia and Herzegovina), livestock, especially cattle and 
sheep, have a long tradition. The potential for the development of animal husbandry is a major, taking into account the available land capacity. On the other hand, consumption of proteins of animal origin grows proportionally with the increase in living standards. Thus, the consumption of these types of proteins in the EU is twice the world average and the trend is increasing because of growth in living standards, due to EU enlargement and increase of population. EU countries cannot meet the needs of the proteins of animal origin from its own resources. EU countries are also moving away from the strategy of further intensification of production of animal products because it would have meant even greater pressure on land resources, biodiversity, and quality and safety of products, and this is not what European producers now want. This situation creates room for producers from RS to create supply for the European market. The aim of this paper is to demonstrate the capabilities and trends in meat production in the Republic of Srpska, and the willingness of this part of the RS economy to compete in the European market.

The authors used the method of comparative analysis to observe the livestock and meat production in the RS in the period 2005-2011. The analyzes investigates the trends in the growth of livestock number, as well as the quantity of meat produced, calculated on the basis of the base index, with 2005 as base year. The data sources used were official publications of the Institute of Statistics. The level of the trade balance has been analyzed trough the value of foreign trade, imports and exports for the period 2005-2009, for which period data were available. The data are taken from official publications of the Foreign Trade Chamber of $\mathrm{BiH}$ and relate to $\mathrm{BiH}$ as a country, given that the foreign trade exchange is in the jurisdiction of the state rather than entity in Bosnia.

The results of the research show that the significance of the development of livestock production is reflected in the fact that the ruminants exploit surface under natural grasslands (meadows and pastures), which in the structure of agricultural land covers about 36\%. According to the indices of production for the base year 2005, we can conclude that all species of livestock other than pigs had a positive index value. The average growth in cattle production compared to 2005 was $8.89 \%$ per year, with highest values in 2006 and the lowest in 2008 . Production of sheep had an average increase of $25.29 \%$ per year, with highest values in 2010 , and lowest in 2006. Production of pigs has not reached the level of production in 2005 and the average index compared to this year was only $83.17 \%$. The lowest index was recorded in 2008 when total production fell to $69.37 \%$ of production in 2005. Poultry production has, as stated above, the highest growth with an average annual rate of $66.14 \%$. The greatest value of poultry production has being reached in 2010 with over $200 \%$ growth index compared to 2005, but in 2011 this index has declined by $30 \%$.

Then, failure of basic safety standards, improper organization of purchasing, quality inconsistency, lack of knowledge of foreign markets, are just some of the reasons why the potential for exports, which exists in this sector, is not used.

Therefore, there is a need to increase livestock production through: better organization of fattening in terms of compliance capacity of primary and secondary production, improving the quality of production especially in terms of ensuring continuity and quality level, improve the situation in the meat production and processing by economic measures, which occurs as a necessary precondition for export, but also use pre-accession funds, including making available soft lending to investment in livestock production, encourage efficient forms of cooperation between producers, feed industry for poultry and processing industries and in that sense, support the establishment of agricultural chambers, which would bring together representatives of all sectors in the chain and allow the establishment of rules and agreements in the field of production and market agricultural products; Establishing laboratories for testing the quality of meat, an increase of work on prevention and combating of infectious diseases in order for $\mathrm{BiH}$ to obtain a license for the export of products of animal origin.

\section{Summary in Serbian}

\section{ТРЕНДОВИ У ПРОИЗВОДЫА И ПРЕРАДИ МЕСА У РЕПУБЛИЦИ СРПСКОЈ}

Један од стратешких циљева економске политике сваке земље је унапређење производње хране, како би се постигли виши нивои самодовољности у прехрамбеним потребама. Из тога проистиче да је производња меса веома важан ресурс за производњу хране, тако да се тој производњи треба дати адекватна правна и институционална подршка. У Републици Српској (Ентитет Босне и Херцеговине), сточарство, а нарочито узгој говеда и оваца, имају дугу традицију. Потенцијал за развој сточарства је велик, узимајући у обзир расположиве капацитете земљишта. С друге стране, потрошња протеина животињског порекла расте пропорционално са повећањем животног стандарда. Потрошња ове врсте протеина у ЕУ је два пута већа од светског просека, и има тренд пораста због раста животног стандарда, проширења ЕУ и повећања популације. Земље ЕУ не могу да задовоље потребе протеина 
животињског порекла из сопствених извора. Земље ЕУ се такође удаљавају од стратегије даљег интензивирања производње анималних производа, јер би то значило још већи притисак на одрживо кориштење земљишних ресурса, биодиверзитет и квалитет и безбедност производа, а то није оно што европски произвођачи сада желе. Ова ситуација ствара простор за произвођаче из РС да створе залихе за европско тржиште. Циљ овог рада је да покаже могућности и трендове у производњи меса у Републици Српској, као и спремност овог дела привреде РС да се такмиче на европском тржишту.

Аутори су користили метод упоредне анализе за посматрање обима сточарске производње и производње меса у РС у периоду 2005-2011. Анализирани су трендови раста броја стоке, као и количине произведеног меса, израчунату на основу базног индекса, са 2005 као базном годином. Као извори података коришћене су званичне публикације Завода за статистику. Ниво трговинског биланса је анализиран преко вредности спољне трговине, увоза и извоза за период 2005-2009, период за који су подаци били доступни. Подаци су узети из званичних публикација Спољнотрговинске коморе БиХ и односе се на БиХ као земљу, с обзиром да је спољнотрговинска размена у Босни и Херцеговини у надлежности државе, а не ентитета.

Резултати истраживања показују да се значај развоја сточарства огледа у чињеници да преживари искориштавају површине под природним травњацима (ливаде и пашњаци), које у структури пољопривредног земљишта покривају око 36\% укупних површина. Према индексима производње у односу на базну годину 2005, можемо закључити да су све врсте стоке, осим свиња имале позитивну вредност индекса. Просечан раст у производњи стоке у односу на 2005 био је 8,89\% годишње, са највишим вредностима у 2006 и најнижим у 2008. Производња оваца имала је просечан раст од $25.29 \%$ годишње, са највишим вредностима у 2010, а најнижим у 2006. Производња свиња није достигла ниво производње из 2005, а просечан индекс у односу на ову годину био је само 83,17\%. Најнижи индекс забиљежен је у 2008 када је укупна производња пала на 69,37\% нивоа производње у 2005. Живинарска производња је, имала највећи раст, са просечном годишњом стопом од 66.14\%. Највећа вредност у живинарској производњи је постигнута у 2010, са преко 200\% раста индекса у односу на 2005, али у 2011 је овај индекс опао за $30 \%$.

С друге стране, неуспех у увођењу основних стандарда безбедности, неправилна организација набавке, неконзистентност квалитета, недостатак знања о страним тржиштима, само су неки од разлога зашто је потенцијал за извоз, који постоји у овом сектору, неискориштен.

Дакле, постоји потреба да се повећа производња стоке кроз: бољу организацију това у смислу усклађености капацитета примарне и секундарне производње, побољшање квалитета производње, посебно у погледу обезбеђивања континуитета и нивоа квалитета, побољшање стања у производњи меса и преради кроз увођење економских мера, које се јављају као неопходан предуслов за извоз, али и искориштавање претприступних фондова, укључујући стављање на располагање кредитирање инвестиција у сточарској производњи, подстицање ефикасних облика сарадње између примарних произвођача, произвођача сточне хране и индустрије за прераду. У том смислу, треба подржавати оснивање пољопривредних комора, које ће окупити представнике свих сектора у ланцу и омогућити успостављање правила и споразума у области производње и тржишта пољопривредних производа; успостављање лабораторија за испитивање квалитета меса, повећање рада на превенцији и борби против заразних болести у циљу да БиХ добије дозволу за извоз производа животињског порекла.

\section{REFERENCES}

European Commission, (2010), DG Agriculture and Rural Development, Country Report, Ministarstvo poljoprivrede šumarstva i vodoprivrede Republike Srbije, 2011, Nacionalni program ruralnog razvoja Srbije od 2011. do 2013. godine, Beograd;

Ministarstvo poljoprivrede, šumarstva i vodoprivrede Republike Srpske, (2009), Informacija o stanju i uslovima privređivanja u prehrambenoj industriji RS za 2008. godinu, page5.

Mirjanić S. et al., (2011), Agrarni sektor Republike Srpske - stanje i pravci razvoja osnovne karakteristike CAP, University of Banja Luka, Faculty of Agriculture;

Mirjanić S., i saradnici, (2010), Ruralni razvoj Republike Srpske, Univerzitet u Banjoj Luci, Faculty of Agriculture; 
Republika Srpska Institute of Statistics, (2010), Annual Statistical Bulletin ISSN 2232-7312, Banja Luka, December, 2010;

The European Union, PBL Netherlands Environmental Assessment Agency, (2011), The protein puzle. The consumption and production of meat, diary and fish, The Hague; 